\title{
AN INVESTIGATION OF CONSUMER BRAND ENGAGEMENT ANTECEDENTS ON IPHONE SMARTPHONE USERS
}

\author{
Yunita Agustina ${ }^{1}$, Faizal Ardiyanto ${ }^{2}$ \\ ${ }^{1,2}$ Universitas PGRI Yogyakarta, Jl. PGRI I Sonosewu No. 117 Yogyakarta 55182, Indonesia \\ e-mails: ${ }^{1}$ yunitaagustinaa@gmail.com; ${ }^{2}$ faizal@upy.ac.id
}

Received May 21, 2020; accepted July 1, 2020; published July 2, 2020.

\begin{abstract}
Objective: This research provides evidence that there are significant and positive influences from three main predictors of CBE (Consumer Brand Engagement) namely consumer involvement, consumer participation, and self-expressive brand on the three dimensions of CBE namely cognitive processing, affection, and activation. Research Design \& Methods: This quantitative research uses purposive sampling which is combined with snowball sampling to collect data from 295 respondents of IPhone smartphone users/consumers at several locations in Indonesia. Structural Equation Modelling - AMOS is used to test the nine hypotheses. Findings: six of nine research hypotheses are significantly and positively supported hypotheses, while the other three hypotheses are not. Implications \& Recommendations: Based on findings, it can be stated that for the Apple Inc. as the owner of IPhone brand should give more experience, encourage participation, and emotional relation to their consumers as they continue using the products. Ideas, critics, and suggestion from consumers are important factors for the brand as well. Contribution \& Value Added: This research provides insight to understand CBE dimensions and its antecedents on IPhone brand, they are consumer involvement, consumer participation, and self-expressive brand on cognitive processing, affection, and activation.
\end{abstract}

Keywords: consumer brand engagement, consumer involvement, consumer participation, selfexpressive brand, IPhone.

JEL codes: M31, M37

Article type: research paper

\section{INTRODUCTION}

Nowadays, a vast majority of new technologies can be found in several aspects of people's lives, one of them is telecommunications technology. The development of communication technology has resulted the needs and desires of individuals to develop themselves as well. In addition, technology is also used as self-actualization. The impact of the development of this new technology is manifested in the form of smartphones that can replace computer performances such as communication, push e-mail, online shopping, browsing, until status updates on social media can cause smartphones use to increase and become necessities of life.

Although smartphones have been developed rapidly in terms of quality and excellence, consumers still have specific and fundamental reasons for choosing and using certain brands. The smartphone brand selection process is supported by several factors that will be taken into account by consumers. There are a large number of smartphone manufacturers in the marketplace, then competition is now not only limited to the smartphone's technology, especially because all of them have features that are easier to use currently. Consumers might prefer to choose smartphone brands over the features offered by the smartphone manufacturers. So, this phenomenon can be an insight for marketers to understand the consumer behaviour pattern associated with smartphone brands chosen by them. 
Consumer brand engagement which is abbreviated as CBE is considered as an important idea because nowadays consumers are offered a large selection of smartphone brands. This causes CBE not only emphasize the competition between features of available smartphone brands, but also as explanation of consumer willingness to continue using certain smartphone brands. Consumers engagement to certain brands is very necessary to gain consumer loyalty, given that the current smartphone brands competition is increasingly widespread. Consumers who have the perception of strong relation to a particular brand of smartphone will be more actively seeking information about the brand itself that they want to buy. Meanwhile, if consumers are not bound by certain smartphone brands, these consumers will not continue using the brand after buying it. By understanding the consumer engagement process, it is expected that the company can find out the position of consumers so that they can be closer to company's brand. In this process, researchers use the consumer brand engagement process model as described by Gambetti et al. (2012). The CBE process consists of three phases which can be marked by the increasing ability of a brand to get closer to its consumers by making these consumers bound to a particular brand. The more consumers are bound to certain brands, the stronger the relationship between brands and consumers. Therefore, these factors are important to be investigated so as to provide an overview of the antecedents that have a significant and positive effect on the dimensions of CBE.

\section{LITERATURE REVIEW}

\section{Consumer Brand Engagement}

Previous research as in the study of Khan et al. (2016) have found that consumers who are bound to brands can be a basis in building stronger relationships between consumers and brands of a particular company. This strong relationship can occur after consumers are bound to certain brands and are willing to continue the relationship after the post-purchase of certain brands. The CBE concept fits in the context of relationship marketing which emphasizes the importance of maintaining loyal valuable consumers (Hollebeek, 2010). Likewise, Pansari \& Kumar (2016) found that to make consumers bound to brands, the relationship between consumers and brands must be good and have emotional ties. Sashi (2012) also defines CBE as a state of consumers who can actively maintain relationships with brands or companies that are characterized by consumer behaviour that helps creating value in the process.

\section{Consumer Involvement}

Based on Zaichkowsky (1985), consumers engagement can be known from the behaviour which they feel, that the product of a brand they own consistently and related with their needs, values, and interests. Therefore, researchers associate these consumer participation with CBE. Russell et al. (2007) defines the involvement that the targeted object is important from the consumer's perspective and how the object relates to the consumer's personal self. While according to Smith \& Godbey (1991) involvement is a cognitive, affective, or motivational construct that shows thought or personal relationships are felt but are not considered as behavioural. Thus, a high level of consumer interest and concern shows that it is an antecedent for the user. According to Beatty \& Smith (1987) involvement results in greater external search and greater cognitive processing. Meanwhile according to Petty \& Cacioppo (1983) participation has more elaboration and according to Robertson (1976) participation increases in product trials.

\section{Consumer Participation}

The concept of voluntary consumer performance that demonstrated through behaviour can help the company's ability to evaluate the services provided in order to provide better service quality (Eisingerich et al. 2014). This means that consumer participation is an important form of consumer voluntary performance that is shown in the customer behaviour to company. Participation refers to the extent to which consumers provide constructive feedback and useful advice to certain companies (Eisingerich et al. 2014). In essence, consumer participation includes the extent to which consumers are involved in the production and evaluation of services provided by companies (Dabholkar, 1990). 
Consumer participation is important so that consumers can actively communicate with companies related to their production (Chen et al. 2011). According to Chan et al. (2010) and Vargo \& Lusch (2004) show that the importance of engaging consumers internally through their participation is important for changes in companies that produce certain brands.

\section{Self-Expressive Brand}

Based on the definition by Carroll \& Ahuvia (2006), self-expressive brand is an extent to which consumers feel the brand they choose can reflect themselves. Belk (1988) asserted that brands can reflect consumers' self through the way consumers think about certain brands and can also provide an extension of themselves through certain brands. Therefore, as stated by Carroll \& Ahuvia (2006), the design of brand symbols is usually used by consumers to form and reflect their identity. However, the number of studies linking the impact of self-expressive brand to the CBE dimension is still limited (Leckie et al. 2016). Although the research is still limited, research from Carroll \& Ahuvia (2006) and Wallace et al. (2014) have shown the impact of self-expressive brand on emotional behaviour. Research from Algesheimer et al. (2005) discusses that brand attachment occurs when consumers' motives are supported by themselves can increase the level of brand engagement. Furthermore, research from Jahn \& Kunz (2012) which suggests that consumers are more likely to be attached to a brand when they feel that the brand can cause them to express themselves in accordance with their personal values. Thus, the value of the consumer's self-concept has a positive impact on brand attachment. In addition, Jahn \& Kunz (2012) also discussed the role of self-expressive brand that can influence their engagement with those brands.

\section{Cognitive Processing}

The first dimension of CBE is cognitive processing. Cognitive processing is a dimension of CBE in the form of the level of knowledge possessed by consumers about a brand. Hollebeek et al. (2014) defines cognitive processing as the consumer level of brand-related thought processes and elaboration in an energy, effect, and time spent on certain brands in consumer interactions with certain brands. Consumers who have high cognitive knowledge or processing about a particular brand, then have a great opportunity to become attached to the brand. The more consumers are bound to certain brands means that consumers can create a strong relationships with certain brands after post-purchase. Leckie et al. (2016) also defines cognitive processing as an interaction between consumers and certain brands. In detail, according to Dessart et al. (2015) cognitive processing can be defined as the attention and absorption carried out by consumers towards a brand. In the context of engagement, cognitive processing refers to the psychology of consumers who are active towards the consumer experience related to the brand that causes them to be bound. Hollebeek et al. (2014) developed a scale for CBE which was subsequently adopted by other studies such as Leckie et al. (2016), Hepola et al. (2017), Tunca (2019), Brandao et al. (2019), and Algharabat et al. (2019). One of the scales of CBE is cognitive processing. According to Hollebeek et al. (2011) cognitive processing associated with CBE is an emotional and behavioral activity that is owned by consumers with a focus on interaction with certain brands.

\section{Affection}

The second dimension of CBE is affection. Affection is a CBE dimension in the form of emotional level possessed by consumers. According to Hollebeek et al. (2014), affection refers to the level of consumers associated with brands that can affect interactions between consumers and certain brands. Hollebeek et al. (2014) chose the emotional dimension of affection in order to be complemented by the benefits received by consumers. According to Dessart et al. (2015) affection can be defined as an enthusiasm and enjoyment which means that affection is a form of emotional levels experienced by consumers with brands that make them bound. This emotional level can occur in the long-term and repeatedly, not just once. Affective dimensions relate to various things in the form of content and interaction. 


\section{Activation}

The third dimension of CBE is activation. Activation is a dimension of CBE in the form of behaviour owned by consumers. Consumer activity or behaviour can be expressed through the level of consumer energy given in interacting with certain brands (Patterson et al. 2006). Meanwhile, according to Hollebeek et al. (2011) activation is defined as the level of energy, effort, and time of consumers spend on an interaction with particular brand, which means that activation is the behaviour of the CBE dimension. Liembawati et al. (2014) defines brand activation as an interconnected unity of all communications available. Furthermore, activation also has a meaning of stimulating interest, testing, loyalty, and new communication tools that introduce something every year and brand activation is one form of company promotion that promotes a particular brand so that it can get closer and build a brand interaction with its users through an activity.

\section{METHODS}

This research explains the phenomenon of consumer brand engagement on IPhone smartphone brand because these brand products tend to be expensive yet consumers still want them. Based on the level of explanation, the type of this research is associative, causal research. According to Sugiyono (2012) associative research is research whose purpose is to find out the relationship between two or more variables. While the causal relationship according to Sugiyono (2012) is the relationship between the independent variable and the dependent variable that has a causal relationship.

Research data is obtained from the respondents through surveys method using questionnaire items via Google Form, which means this research uses primary data. Furthermore, this type of research is quantitative. Researchers used a combination of non-probability sampling techniques, namely snowball sampling and purposive sampling. According to Nurdiani (2014) snowball sampling is the right method used to form a network of continuous relationships. This continuous relationship occurred because researchers initially distributed online questionnaires using Google Form to initial respondents. Furthermore, the initial respondent distributes the questionnaire link to other people who can become the next respondents, thereby increasing the number of questionnaires and data obtained (Ardiyanto \& Kusumadewi, 2018). Nevertheless the data obtained from these respondents cannot be used entirely as samples because the researchers used purposive sampling as well. Purposive sampling is the determination of the number of respondents from the population who have certain criteria, including (1) once bought IPhone smartphone; (2) IPhone smartphone users; and (3) using an IPhone smartphone for 1 month and more. Statement items were measured using five Likert scales of the highest score, namely Strongly Agree (SS) as 5 in score and the lowest score Strongly Disagree (STS) as the score of 1 . While the number of respondents obtained was 295 people from several locations or provinces in Indonesia especially in Java Island.

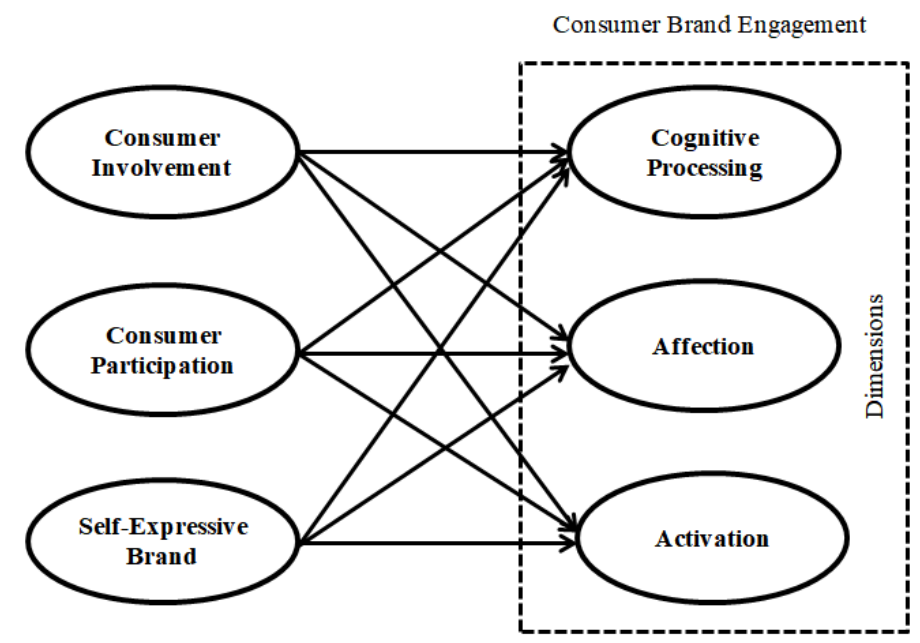

Figure 1. Research Hypothesis Model 
Tabel 1. Instrument of Measurement Variables

\begin{tabular}{|c|c|}
\hline Variables & Items \\
\hline Consumer & Based on my attitude towards the IPhone smartphone, I feel that the brand is important. \\
\hline \multirow[t]{3}{*}{ Involvement } & $\begin{array}{l}\text { Based on my personal values towards the IPhone smartphone, I feel that the brand is } \\
\text { important. }\end{array}$ \\
\hline & The IPhone brand is very important to me. \\
\hline & The IPhone brand is more important to me compared to other brand. \\
\hline Consumer & If I have a useful idea to improve the IPhone brand, I will tell them. \\
\hline \multirow[t]{3}{*}{ Participation } & I give constructive advice to the IPhone brand on how to improve the service. \\
\hline & I told the IPhone about how to serve consumers well. \\
\hline & I provide many useful ideas and suggestions to enhance the IPhone brand. \\
\hline Self- & The IPhone brand reflects my true self. \\
\hline Expressive & The IPhone brand enhance my self-image. \\
\hline \multirow[t]{2}{*}{ Brand } & The IPhone brand contributes to my self-image. \\
\hline & The IPhone brand adds to the social "role" that I play. \\
\hline Cognitive & I think IPhone brand a lot when I use it. \\
\hline \multirow{3}{*}{ Processing } & Time flies so fast when I use the IPhone brand. \\
\hline & I don't want to be disturbed when using the IPhone brand. \\
\hline & I really enjoy using and interacting with the IPhone brand. \\
\hline \multirow[t]{4}{*}{ Affection } & Using the IPhone brand makes me happy. \\
\hline & I feel good when using the IPhone brand. \\
\hline & Smartphone from IPhone brand makes me feel happy \\
\hline & Smartphone from IPhone brand makes me feel entertained. \\
\hline \multirow[t]{3}{*}{ Activation } & I often use the IPhone brand compared to other brand \\
\hline & I use IPhone smartphone brand from time to time. \\
\hline & I most often use the IPhone brand. \\
\hline
\end{tabular}

\section{FINDING}

The following table depicts the demographic data of respondents presented through the frequency table. The function of this demographic data is to determine the background demographic factors (population) of respondents based on categories of domicile, gender, age, education, occupation, and income.

\section{(Tabel 2, See Appendix 1)}

Table 2 shows the characteristics of respondents based on domicile are dominated by respondents from Yogyakarta Special Region which consist of 241 people or $81.7 \%$. For the characteristics of respondents by sex are dominated by women which consist of 194 people or $65.8 \%$. In terms of age, respondents who use IPhone smartphone brands are dominated by respondents 21-25 years old or percentage of 59.3\%. In terms of education, it can be concluded that respondents who own and use IPhone smartphone brand are dominated by respondents who have a high school / vocational / equivalent education totalling 155 people or $52.6 \%$. In terms of occupation, the characteristics of respondents were dominated by students which consist of 146 people or $49.5 \%$. While based on monthly income the characteristics of respondents owners and users of IPhone smartphone brand are dominated by respondents who earn Rp1,000,500 - Rp2,000,000 which consist of 119 people or $40.3 \%$.

\section{Convergent Validity and Composite Reliability Tests}

\section{Convergent Validity}

Tabel 3. Items Convergent Validity Test Result

\begin{tabular}{|c|c|c|}
\hline Variables & Items & Factor Loadings \\
\hline Consumer Involvement & 1 & 0.925 \\
\hline & 2 & 0.904 \\
\hline
\end{tabular}




\begin{tabular}{|c|c|c|}
\hline Variables & Items & Factor Loadings \\
\hline & 4 & 0.762 \\
\hline \multirow[t]{4}{*}{ Consumer Participation } & 1 & 0.764 \\
\hline & 2 & 0.887 \\
\hline & 3 & 0.889 \\
\hline & 4 & 0.787 \\
\hline \multirow[t]{4}{*}{ Self-Expressive Brand } & 1 & 0.795 \\
\hline & 2 & 0.914 \\
\hline & 3 & 0.917 \\
\hline & 4 & 0.900 \\
\hline \multirow[t]{4}{*}{ Cognitive Processing } & 1 & 0.706 \\
\hline & 2 & 0.801 \\
\hline & 3 & 0.839 \\
\hline & 4 & 0.841 \\
\hline \multirow[t]{4}{*}{ Affection } & 1 & 0.911 \\
\hline & 2 & 0.887 \\
\hline & 3 & 0.881 \\
\hline & 4 & 0.822 \\
\hline \multirow[t]{3}{*}{ Activation } & 1 & 0.905 \\
\hline & 2 & 0.590 \\
\hline & 3 & 0.904 \\
\hline
\end{tabular}

Source: primary data processed

Table 3. shows that all items for each research variables have Factor Loading score $\geq 0.50$ so that it can be interpreted that all items are valid. It also can be concluded that, each statement items in the questionnaire can be used to measure the research variables.

\section{Composite Reliability}

Tabel 4. Composite Reliability Test Result

\begin{tabular}{|c|c|c|}
\hline Variables & Items & Composite Reliability (CR) \\
\hline Consumer Involvement & 4 & 0.922 \\
\hline Consumer Participation & 4 & 0.901 \\
\hline Self-Expressive Brand & 4 & 0.934 \\
\hline Cognitive Processing & 4 & 0.875 \\
\hline Affection & 4 & 0.929 \\
\hline Activation & 3 & 0.850 \\
\hline
\end{tabular}

Source: primary data processed

Table 4 above shows that all statement items for each research variable obtain Composite Reliability (CR) score of more than 0.6 so that all items meet the reliability requirements. Therefore, all items of the statement are consistent. Composite Reliability is consistent which means each item of the statement can be used for further studies.

\section{Model Fit Test}

Tabel 5. Model Fit

\begin{tabular}{lccc}
\hline \multicolumn{1}{c}{ Model fit indices } & Recommended Score & Result Score & Model Evaluation \\
\hline Absolute Fit Measures & & & \\
Chi-square $\left(\chi^{2}\right)$ & Expected to be low & 608.50 & Bad fit \\
$\chi^{2} /$ d.f. & $<2$ fit, $2-5$ reasonable & 2.791 & Reasonable \\
GFI & $\geq 0.90$ & 0.846 & Marginal fit \\
RMSEA & $\leq 0.08$ & 0.078 & Good fit \\
Incremental Fit Measures & & & Good fit \\
AGFI & $\geq 0.80$ & 0.805 & Good fit \\
TLI & $\geq 0.90$ & 0.923 & Good fit \\
NFI & $\geq 0.90$ & 0.900 & \\
\hline
\end{tabular}

Recommended score is adapted from Ghozali (2016) and Wang et al. (2006)

Source: Primary Data Processed (2019) 
Based on absolute fit measurements in table 5 above, it can be concluded that the score of CMIN or Chi-square $(\chi 2)$ is 608.50. CMIN score itself is expected to be low so based on the results of these calculations, the model fit is included in bad fit category. The CMINDF score or $\chi^{2} / \mathrm{d}$.f is 2.791 . The score for the CMINDF mentioned $<2$ is fit, $2-5$ is reasonable. Because it gets score of 2.791, so this is included in the reasonable category, in other words it can be accepted for certain reasons. The score of GFI (Goodness of Fit Index) that close to 1.0 is categorized as perfect fit. While the results of GFI in this research is 0.846 , so it is included in the marginal fit category. It means that the fit model is quite good and acceptable. While the score of RMSEA (Root Mean Square Error of Approximation) obtained in this fit model is 0.078 while the recommended score is less than 0.08 so that the results of the RMSEA fit model are good fit.

Based on the incremental fit measurement table 5 above, it can be concluded that the score of the AGFI (Adjusted Goodness of Fit) in this model fit is 0.805 or exceeds the recommended score of 0.80 so that it can be categorized as good fit. While the TLI (Tucker Lewis Index) score obtained in this fit model is 0.923 while the recommended score is 0.90 , so this means that the TLI index is categorized as good fit. Furthermore, the score of NFI obtained is 0.900 while the recommended score should be 0.90 so that it can be concluded that the NFI in this fit model is categorized as good fit.

\section{Hypothesis Test}

Tabel 6. Hypothesis Test Result

\begin{tabular}{|c|c|c|c|}
\hline Hypothesis & $\begin{array}{c}\text { Standardized } \\
\text { Regression } \\
\text { Weights (ß) }\end{array}$ & $p$-value & Results \\
\hline $\begin{array}{l}\left(\mathrm{H}_{1}\right) \text { Consumer involvement significantly and positively } \\
\text { influences cognitive processing. }\end{array}$ & -0.029 & 0.651 & Not Supported \\
\hline $\begin{array}{l}\left(\mathrm{H}_{2}\right) \text { Consumer involvement significantly and positively } \\
\text { influences affection. }\end{array}$ & 0.028 & 0.666 & Not Supported \\
\hline $\begin{array}{l}\left(\mathrm{H}_{3}\right) \text { Consumer involvement significantly and positively } \\
\text { influences activation }\end{array}$ & 0.314 & $<0.001$ & Supported \\
\hline $\begin{array}{l}\left(\mathrm{H}_{4}\right) \text { Consumer participation significantly and positively } \\
\text { influences cognitive processing. }\end{array}$ & 0.335 & $<0.001$ & Supported \\
\hline $\begin{array}{l}\left(\mathrm{H}_{5}\right) \text { Consumer participation significantly and positively } \\
\text { influences affection. }\end{array}$ & 0.145 & 0.002 & Supported \\
\hline $\begin{array}{l}\left(\mathrm{H}_{6}\right) \text { Consumer participation significantly and positively } \\
\text { influences activation. }\end{array}$ & 0.003 & 0.957 & Not Supported \\
\hline $\begin{array}{l}\left(\mathrm{H}_{7}\right) \text { Self-expressive brand significantly and positively } \\
\text { influences cognitive processing. }\end{array}$ & 0.665 & $<0.001$ & Supported \\
\hline $\begin{array}{l}\left(\mathrm{H}_{8}\right) \text { Self-expressive brand significantly and positively } \\
\text { influences affection. }\end{array}$ & 0.704 & $<0.001$ & Supported \\
\hline $\begin{array}{l}\left(\mathrm{H}_{9}\right) \text { Self-expressive brand significantly and positively } \\
\text { influences activation. }\end{array}$ & 0.406 & $<0.001$ & Supported \\
\hline
\end{tabular}

Source: Primary Data Processed (2019)

Based on tabel 6 above, it can be concluded that hypothesis $\mathrm{H} 3, \mathrm{H} 4, \mathrm{H} 5, \mathrm{H} 7, \mathrm{H} 8$, and $\mathrm{H} 9$ are proved to be supported because based on SEM-AMOS testing, the p-value is less than 0.05. As for hypothesis $\mathrm{H} 1, \mathrm{H} 2$, and $\mathrm{H} 6$ are proved not supported because they have p-value more than 0.05 .

\section{DISCUSSION}

Based on the results of hypothesis testing in table 6, it can be seen that $\mathrm{H} 1$ is proved not supported because the $p$-value obtained is 0.651 and a $\beta$ value of -0.029 . Therefore, it can be concluded that the consumer involvement variable does not affect cognitive processing variable significantly. $\mathrm{H} 2$ also proved not supported because the p-value obtained is 0.666 and $\beta$ was 0.028 . Therefore, it can also be concluded that the consumer involvement variable does not affect the affection variable significantly. Whereas in the third hypothesis, H3 is proved to be supported because the p-value obtained is less than 0.001 and $B$ at 0.314 so that the consumer involvement variable significantly and positively influences activation variable, the higher the consumer involvement in the IPhone smartphone brand, the 
activation or behaviour of the consumer towards the IPhone smartphone brand also increased. For $\mathrm{H} 4$ proved to be supported because the $p$-value obtained is less than 0.001 and $\beta$ of 0.335 so that the consumer participation variable has a significant and positive effect on cognitive processing variables, the greater the participation of IPhone smartphone brand consumers, the cognitive processing or the level of consumer knowledge about iPhone smartphone brands also increased.

$\mathrm{H} 5$ is proved to be supported because p-value obtained is 0.002 and $\beta$ of 0.145 so that the consumer participation variable has significant and positive effect on the affection variable, which means that more consumers participate in IPhone smartphone brand, the affection or consumer's emotion will also increasingly high. H6 is proved to be not supported because p-value of 0.957 and a $B$ value of 0.03 . Thus it can be concluded that the consumer participation variable has no significant effect on the activation variable.

$\mathrm{H} 7$ is supported with a p-value obtained less than 0.001 and $\mathrm{B}$ of 0.665 so that the self-expressive brand has significant and positive effect on cognitive processing variables, the higher the consumer's self-expressive brand of Iphone smartphone, the cognitive processing or the level of knowledge towards the iPhone smartphone brand also increased. Furthermore, $\mathrm{H} 8$ is proved supported because pvalues obtained is less than 0.001 and $\beta$ of 0.704 so that the self-expressive brand has significant and positive effect on the affection variable, the greater the brand that can express itself as consumers of Iphone smartphone brands, the consumer's affection or emotional level have also increased. The last hypothesis is that H9 is proven to be supported with p-value obtained is less than 0.001 and $B$ of 0.406 so that the self-expressive brand has significant and positive effect on the activation variable, which means the higher the brand that expresses itself to the IPhone consumers, the activation or consumer action towards the iPhone smartphone brand also higher.

\section{CONCLUSION}

This research on consumers/users of IPhone smartphone brand using SEM-AMOS analysis regarding consumer involvement, consumer participation, and self-expressive brand to the dimensions of CBE namely cognitive processing, affection, and activation, can be drawn following conclusions (1) consumer involvement has no significant and positive effect on cognitive processing; (2) consumer involvement has no significant and positive effect on affection; (3) consumer involvement has significant and positive effect on the activation; (4) consumer participation has significant and positive effect on cognitive processing; (5) consumer participation has significant and positive effect on the affection; (6) consumer participation has no significant and positive effect on the activation; (7) selfexpressive brand has significant and positive effect on affection; (8) self-expressive brand has significant and positive effect on cognitive processing; (9) self-expressive brand has significant and positive effect on cognitive processing.

The results of this research can provide recommendation to IPhone about consumer involvement which only affects the one dimension of $\mathrm{CBE}$, which is activation. Related to cognitive processing, IPhone must provide more knowledge and feelings to consumers so they can engage with the IPhone brand and ultimately can continue the relationship towards the brand. Furthermore, consumer involvement has no effect on affection, which means companies must get consumers involved by creating emotional ties to consumers so that they want to continue using iPhone smartphone brand in a long time. Lastly, consumer participation has no effect on activation, which means companies must encourage consumers to take action to provide ideas, criticisms, and suggestions on IPhone smartphone brand services so that consumers can participate on any IPhone smartphone brand events if needed. Therefore, IPhone must build an IPhone brand services in consideration with consumer's needs and wants in order to continue in getting a place in the hearts of consumers.

\section{REFERENCES}

Algesheimer, R., Dholakia, U. M., \& Herrmann, A. (2005). The Social Influence of Brand Community: Evidence from European Car Clubs. Journal of Marketing, Volume: 69(Issue: 3), 19-34. 
Algharabat, R., Rana, N. P., Alalwan, A. A., Baabdullah, A., \& Gupta, A. (2019). Investigating the antecedents of customer brand engagement and consumer-based brand equity in social media. Journal of Retailing and Consumer Services (https://doi.org/10.1016/j.jretconser.2019.01.016), $1-13$.

Ardiyanto, F., \& Kusumadewi, H. (2018). Anteseden Intensi Belanja Pengguna Aplikasi Website Toko Online di Yogyakarta. Wahana, Volume 21, No. 2, 110-124.

Beatty, S. E., \& Smith, S. M. (1987). External Search Effort: An Investigation across Several Product Categories. Journal of Consumer Research, Vol. 14(Issue 1), 83-95.

Belk, R. W. (1988). Possessions and the extended self. Journal of Consumer Research, 15(2), 139168.

Brandao, A., Pinho, E., \& Rodrigues, P. (2019). Antecedents and Consequences of Luxury Brand Engagement in Social Media. Spanish Journal of Marketing, Vol. 23 No. 2(www.emeraldinsight.com/2444-9709.htm), 163-183.

Carroll, B. A., \& Ahuvia, A. C. (2006). Some antecedents and outcomes of brand love. Marketing Letters, 17, 79-89.

Chan, K. W., Yim, C. K., \& Lam, S. S. (2010). Is Customer Participation in Value Creation a DoubleEdged Sword? Evidence from Professional Financial Services Across Cultures. Journal of Marketing, 74(3), 48-64.

Chen, J.-S., Ching, R. K., \& Tsou, H.-T. (2011). Co-production and its effects on service innovation. Industrial Marketing Management, 40(8), 1331-1346.

Cheung, C. M., Lee, M. K., \& Jin, X.-L. (2011). Customer engagement in an online social platform : A conceptual model and scale development. Department of Information Systems, 4, 3105-3112.

Dabholkar, P. (1990). How to Improve Perceived Service Quality by Improving Customer Participation. Developments in Marketing Science, Academy of Marketing Science, Cullowhee, 483-487.

Dessart, L., Morgan-Thomas, A., \& Veloutsou, C. (2015). Consumer engagement in online brand communities: A social media perspective. Journal of Product \& Brand Management, Vol. 24 Iss $1,28-42$.

Eisingerich, A. B., Auh, S., \& Merlo, O. (2014). Acta Non Verba? The Role of Customer Participation and Word of Mouth in the Relationship Between Service Firms' Customer Satisfaction and Sales Performance. Journal of Service Research, Vol 17(1), 40-53.

Gambetti, R. C., Graffigna, G., \& Biraghi, S. (2012). The Grounded Theory approach to consumerbrand engagement. International Journal of Market Research, Vol. 54(5), 659-687.

Ghozali, I. (2016). Aplikasi Analisis Multivariete Dengan Program (IBM (Edisi 8 ed.). Semarang: Badan Penerbit Universitas Diponegoro.

Hepola, J., Karjaluoto, H., \& Hintikka, A. (2017). The effect of sensory brand experience and involvement on brand equity directly and indirectly through Consumer Brand Engagement. Journal of Product \& Brand Management, Vol. 26 No. 3(https://doi.org/10.1108/JPBM-10-20161348), 282-293.

Hollebeek, L. D. (2010). Demystifying customer brand engagement: Exploring the loyalty nexus. Journal of Marketing Management, Volume 27(Issue 7-8), 785-807.

Hollebeek, L. D. (2011). Exploring customer brand engagement: definition and themes. Journal of Strategic Marketing, Volume 19(Issue 7), 555-573.

Hollebeek, L. D., Glynn, M. S., \& Brodie, R. J. (2014). Consumer Brand Engagement in Sosial Media: Conceptalization, Scale Development, and Validation. Journal of Interactive Marketing, 149165.

Jahn, B., \& Kunz, W. H. (2012). How to Transform Consumers into Fans of Your Brand. Journal of Service Management, 23(3), 344-361.

Kabadayi, E. T., \& Alan, A. K. (2012). Brand Trust and Brand Affect:Their Strategic Importance on Brand Loyalti. Journal of Global Strategic Management, 11, 80-88.

Khan, I., Rahman, Z., \& Fatma, M. (2016). The role of customer brand engagement and brand experience in online banking. International Journal of Bank Marketing, Vol. 34(Iss 7), 10251041.

Leckie, C., Nyadzayo, M. W., \& Johnson, L. W. (2016). Antecedents of Consumer Brand Engagement 
and Brand Loyalty. Journal of Marketing Management, Vol. 32, NOS. 56(http://dx.doi.org/10.1080/0267257X.2015.1131735), 558-578.

Liembawati, Y., Dharmayanti, D., Karina, R., \& Brahmana. (2014). Analisa Pengaruh Brand Activation terhadap Pembentukan Brand Community pada PT ISM Bogasari Flour Mills. Jurnal Manajemen Pemasaran Petra, Vol. 2, No. 1, 1-15.

Malär, L., Krohmer, H., Hoyer, W. D., \& Nyffenegger, B. (2011). Emotional Brand Attachment and Brand Personality: The Relative Importance of the Actual and the Ideal Self. Journal of Marketing, Volume: 75(Issue: 4), 35-52.

Nurdiani, N. (2014). Teknik Sampling Snowball dalam Penelitian Lapangan. ComTech: Computer, Mathematics and Engineering Applications, 5(2), 1110.

Pansari, A., \& Kumar, V. (2016). Customer engagement: the construct, antecedents,and consequences. (M. Houston, Ed.) J. of the Acad. Mark. Sci., 294-311.

Patterson , P., Yu, T., \& De , R. K. (2006, December 4-6). Understanding Customer Engagement in Services, Proceedings of ANZMAC 2006 Conference, Brisbane.

Petty, R. E., Cacioppo, J. T., \& Schumann, D. (1983). Central and Peripheral Routes to Advertising Effectiveness: The Moderating Role of Involvement. Journal of Consumer Research, Vol. 10, No. 2, 135-146.

Robertson, T. S. (1976). Low-Commitment Consumer Behavior. Journal of Advertising Research, 1924.

Russell-Bennett, R., McColl-Kennedy, J. R., \& Coote, L. V. (2007). Involvement, satisfaction, and brand loyalty in a small business services setting. Journal of Business Research, 60(12), 12531260.

Sashi, C. M. (2012). Customer engagement, buyer-seller relationships, and social media. Management Decision, Vol. 50 No. 2, 253-272.

Smith, S. L., \& Godbey, G. C. (1991). Leisure, Recreation and Tourism. Annals of Tourism Research, $18((3)), 85-100$.

Sugiyono. (2012). Metode Penelitian Kuantitatif Kualitatif dan R\&D. Bandung: Alfabeta.

Tunca, B. (2019). Consumer Brand Engagement in Social Media: A Pre-Registered Replication. Journal of Empirical Generalisations in Marketing Science, Vol 19, No. 1, 1-20.

Vargo, S. L., \& Lusch, R. F. (2004). Evolving to a New Dominant Logic for Marketing. Journal of Marketing, Volume: 68(Issue: 1), 1-17.

Wallace, E., Buil, I., \& Chernatony, L. d. (2014). Consumer engagement with self-expressive brands: brand love and WOM outcomes. Journal of Product \& Brand Management, Vol. 23(Iss 1), 33 42.

Wang, Y.-S., Lin, H.-H., \& Luarn, P. (2006). Predicting consumer intention to use mobile. Information Systems Journal, 16, 157-179.

Zaichkowsky, J. L. (1985). Measuring the Involvement Construct. Journal of Consumer Research, Volume 12(Issue 3), 341-352. 


\section{Appendix}

\begin{tabular}{|c|c|c|}
\hline Demographic & Respondents & In Percentage \\
\hline \multicolumn{3}{|l|}{ Domicile } \\
\hline \multicolumn{3}{|l|}{ Java Island } \\
\hline Banten & 5 & 1.7 \\
\hline DKI Jakarta & 9 & 3.0 \\
\hline Jawa Barat & 4 & 1.4 \\
\hline Jawa Tengah & 22 & 7.4 \\
\hline Jawa Timur & 4 & 1.4 \\
\hline Daerah Istimewa Yogyakarta (DIY) & 241 & 81.7 \\
\hline Other location & 10 & 3.4 \\
\hline Total & 295 & 100 \\
\hline \multicolumn{3}{|l|}{ Sex } \\
\hline Male & 101 & 34.2 \\
\hline Female & 194 & 65.8 \\
\hline Total & 295 & 100 \\
\hline \multicolumn{3}{|l|}{ Age } \\
\hline$<15$ years old & 4 & 1.4 \\
\hline $15-20$ years old & 67 & 22.7 \\
\hline $21-25$ years old & 175 & 59.3 \\
\hline $26-30$ years old & 29 & 9.8 \\
\hline $30-35$ years old & 14 & 4.8 \\
\hline $35-40$ years old & 6 & 2.0 \\
\hline Total & 295 & 100 \\
\hline \multicolumn{3}{|l|}{ Education } \\
\hline Junior High School/Equal & 16 & 5.4 \\
\hline High School/Equal & 155 & 52.6 \\
\hline D1 & 1 & 0.3 \\
\hline D3 & 31 & 10.5 \\
\hline Bachelor Degree & 89 & 30.2 \\
\hline Master Degree & 2 & 0.7 \\
\hline Doctoral Degree & 1 & 0.3 \\
\hline Total & 295 & 100 \\
\hline \multicolumn{3}{|l|}{$J o b$} \\
\hline Unemployed & 3 & 1.0 \\
\hline Photographer & 2 & 0.7 \\
\hline Freelancer & 4 & 1.4 \\
\hline Teacher & 2 & 0.7 \\
\hline Housewife & 5 & 1.7 \\
\hline College Students & 146 & 49.5 \\
\hline Private Employees & 81 & 27.4 \\
\hline Students & 23 & 7.8 \\
\hline Businessman & 19 & 6.4 \\
\hline Civil Servant & 10 & 3.4 \\
\hline Total & 295 & 100 \\
\hline \multicolumn{3}{|l|}{ Income (in Rupiahs) } \\
\hline$<1.000 .500$ & 87 & 29.5 \\
\hline $1.000 .500-2.000 .000$ & 119 & 40.3 \\
\hline $2.000 .500-3.000 .000$ & 42 & 14.2 \\
\hline $3.000 .500-4.000 .000$ & 20 & 6.8 \\
\hline $4.000 .500-5.000 .000$ & 15 & 5.1 \\
\hline$>5.000 .500$ & 12 & 4.1 \\
\hline Total & 295 & 100 \\
\hline
\end{tabular}

